\title{
Teleios in the Epistle of James
}

\author{
Seongjae Yeo \\ Department of New Testament and Related Literature \\ Faculty of Theology and Religion, University of Pretoria, South Africa \\ Email: lawmanysj@gmail.com \\ Orcid ID: https://orcid.org/0000-0002-2356-1850
}

Doi:

\begin{abstract}
Teleios is an Hellenistic Greek term which refers to an end, goal, purpose or aim, and it means complete, mature, or fully developed, finished. Teleios signifies consummate soundness, and it includes the idea of being whole. In its numerous forms the term teleios arises 100 times in the Greek New Testament. The term was frequently used in the Epistle of

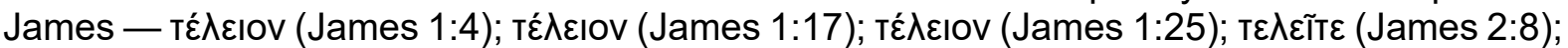

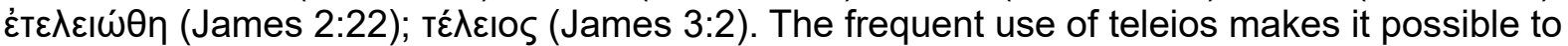
know that the author clearly expressed his perspective through this word. In the previous research on teleios, Patrick J. Hartin argues that the use of teleios in the Epistle of James is rooted in the Hebrew Scriptures and the LXX as a Jewish coloured term. Hartin's view is fair to illuminate that teleios is based on the concept of state of the completeness and whole hearted mental state. Yet, considering that teleios (James 3:2) is used for explaining the process into completeness, called, maturity, such a view of the author of James' Epistle is closer to the view of the Classical Greek Philosopher, Plato, or the Hellenistic Jewish philosopher, Philo of Alexandria. In addition, teleios (James 1:17) which can be regarded as one of the divine attributes, might be traced back to Platonic or Philonic thinking. Thus, James' author might be considered as a Hellenised Jew who combined a Jewish concept with a Hellenistic perspective through the term, teleios.
\end{abstract}

Keywords: Teleios, Maturity, Divine Attribute, Philo, Plato

\section{Introduction}

Hartin (2012:22) summarises his study of the use of teleios in the Old Testament by identifying three essential aspects, thereby assuming that teleios in the Old Testament is the background of teleios in the Epistle of James:

The conceptual meaning of teleios gives expression to three essential dimensions. First, it expresses the idea of wholeness or completeness, of a being remaining true to its original constitution. Second, it refers to giving oneself wholeheartedly and unconditionally to God in the context of God's people. When persons were grounded in this relationship, they would be whole, perfect. Third, such a wholehearted dedication to the Lord is expressed through obedience to God's will. Since the Torah expresses God's will for God's people, a wholehearted dedication to the Lord embraces a life led in obedience to the Torah, to the laws of the Lord. This threefold understanding of teleios explains James' meaning.

Hartin's attempt to encapsulate the meaning of teleios in the Epistle of James is based on the observation that teleios can refer to the state of completeness or psychic wholeness. Yet, other semantic aspects as to teleios are observed in the Epistle of James - teleios as "maturity" and teleios as one of the divine attributes. Thus, it is asked to trace the origin of teleios as 
"maturity" and teleios as one of the divine attributes. For this, one will revisit the epitome of teleios in Jewish lineage tradition (e.g., Hebrew Old Testament, Greek Old Testament, and Qumran), rechecking the validity of Hartin's view and further, will reveal that teleios in the Epistle of James owes much to the thought of Philo and Plato, centring on maturity and divine attribute through intertextual relevance between the text of the Epistle of James and that of Philo and Plato's text.

\section{Teleios in the Greek Old Testament}

Hebrew tamim translated as Greek teleios refers to complete (unblemished) offerings from a cultic viewpoint (Exodus 12:5). That means teleios in Exodus 12:5 refers to "the perfection of state".

\begin{tabular}{|c|c|c|}
\hline \multicolumn{3}{|c|}{ Exodus $12: 5$} \\
\hline 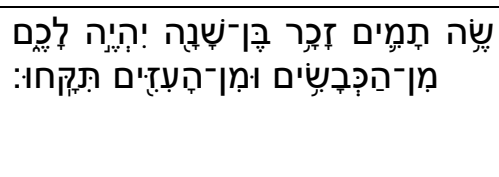 & 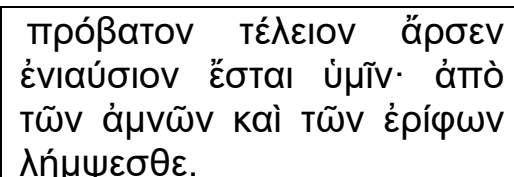 & $\begin{array}{l}\text { Your lamb shall be without } \\
\text { blemish, a year-old male; } \\
\text { you may take it from the } \\
\text { sheep or from the goats. }\end{array}$ \\
\hline
\end{tabular}

In Deuteronomy 18:13, the Hebrew tamim rendered as teleios is a term related to loyalty to God, namely whole-hearted dedication (Pennington, 2017:72).

\begin{tabular}{|c|c|c|}
\hline \multicolumn{3}{|c|}{ Deuteronomy $18: 13$} \\
\hline 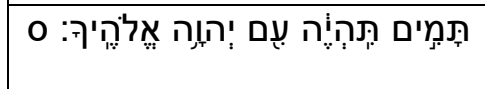 & 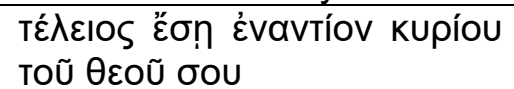 & $\begin{array}{l}\text { You must remain completely } \\
\text { loyal to the Lord your God. }\end{array}$ \\
\hline
\end{tabular}

\section{Teleios in Qumran}

1 QS 8.25-26; 9.1-2 connects the notion of "perfection" into the matter of "purity". As his way is perfect, he can be enrolled in the community of holiness. Thus, Newton (1985:39) defines that "purity is a prerequisite of perfection" as to the concept of perfection in Qumran.

$$
\text { 1QS 8.25-26 }
$$

25 אשר לוא ישפוט איש ולוא [יש[אל על כול עצה

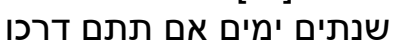

26 במושב במדרש ובעצה [ע]ל] פי [הרבים אם לוא דואים

שגג עוד עד מולאת לו שנתים אים
25 «He may not judge anyone and [he may] not [be a]sked any advice for two whole years». If his conduct is perfect

26 in the session, in the investigation, and in the council [ac]cor[ding to] the Many, if he has not sinned again through oversight until two full years have passed.

\section{QS 9.1-2}

1 כיא על \}.... שגגה אחת יענש שנתים ולעושה ביד

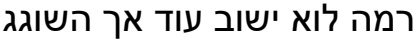

2 יבחן שנתים ימים לתמים דרכו ועצתו על פי הרבים ואחר יכתוב בתכונו ליחד קודש הרים
1 Because for $\{\ldots\}$ one sin of oversight he will be punished two years; but whoever acts impertinently shall not return again. Only someone who sins through oversight 2 shall be tested for two full years with respect to the perfectness of his behaviour and of his counsel according to the authority of the Many, and shall then be enrolled according to his rank in the Community of holiness. 
Given that in James 4:8, "double - hearts" is regarded as the antithesis of "perfection" (teleios), it is fair to judge that the matter of "double - hearts" and purity revealed in James 4:8 owes to the notion from Qumran illuminating the notion of perfection and purity: $\dot{\varepsilon} ү ү i ́ \sigma \alpha T \varepsilon$ те̣ $\theta \varepsilon \tilde{\varphi}$ kaì

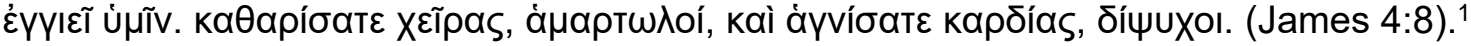

\section{Intertextual Relevance between the Writings of the Epistle of James and Plato's Writings (or Philo's Writings), centering on teleios (maturity)}

In Old Testament, bridle imagery is observed (Job 30:11; 41:13; Psalms 32:9), delivering the motif of controlling or restraint. Even as in James 3:1-3, bridle imagery is associated with controlling the tongue (Psalms 39:1). However, Plato and Philo's works may be candidates for the intertextual research of teleios (maturity) revealed in James 3:1-3 if one notes conceptual interconnections between "horse imagery", the notion of "controlling" and "teleios (maturity)".

\section{Plato, Laws 653 A-E}

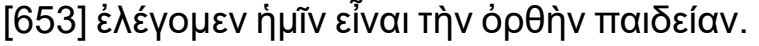

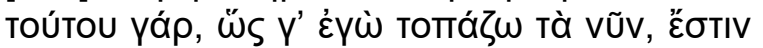

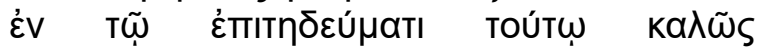

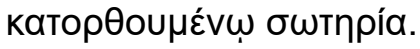

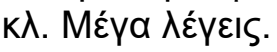

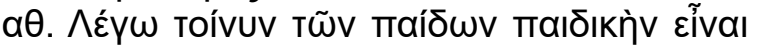

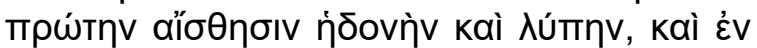

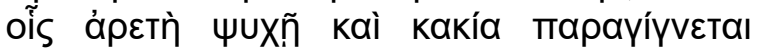

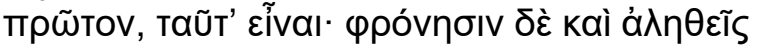

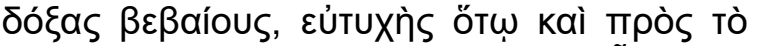

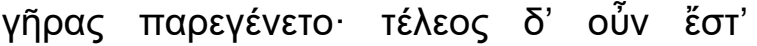

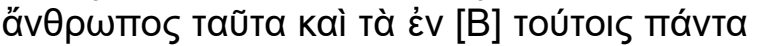

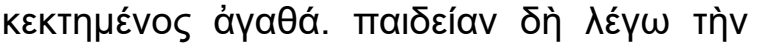

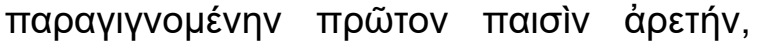

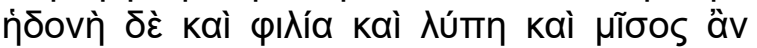

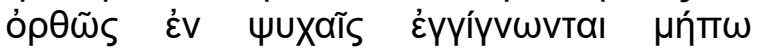

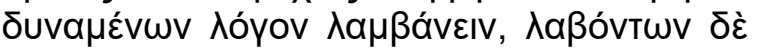

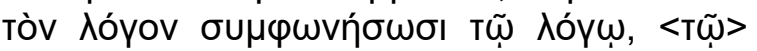

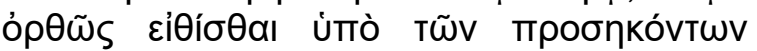

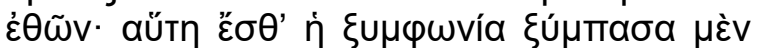

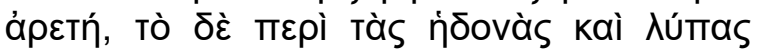

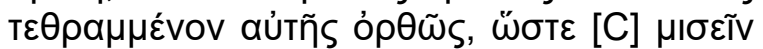

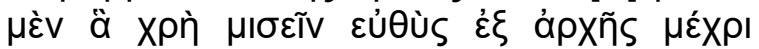

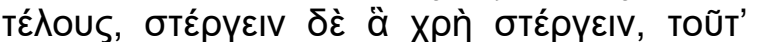

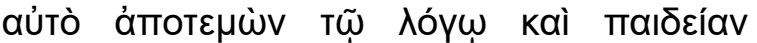

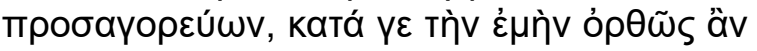
пробаүорвúols.

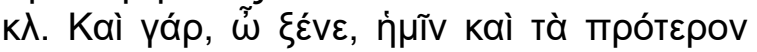

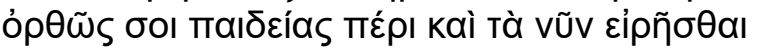
ठОКЕाٓ.

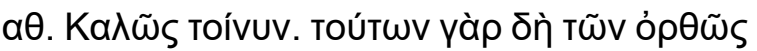

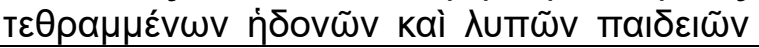

[653] our definition of right education. For the safe-keeping of this depends, as I now conjecture, upon the correct establishment of the institution mentioned.

clin. That is a strong statement!

ath. What I state is this, - that in children the first childish sensations are pleasure and pain, and that it is in these first that goodness and badness come to the soul; but as to wisdom and settled true opinions, a man is lucky if they come to him even in old age; and he that is possessed of these blessings, and all that they comprise, $[\mathrm{B}]$ is indeed a perfect man. I term, then, the goodness that first comes to children "education." When pleasure and love, and pain and hatred, spring up rightly in the souls of those who are unable as yet to grasp a rational account; and when, after grasping the rational account, they consent thereunto through having been rightly trained in fitting practices:- this consent, viewed as a whole, is goodness, while the part of it that is rightly trained in respect of pleasures and pains, so as to hate what ought to be hated, right from the beginning $[\mathrm{C}]$ up to the very end, and to love what ought to be loved,- -if you were to mark this part off in your definition and call it "education," you would be giving it, in my opinion, its right name.

clin. You are quite right, Stranger, as it seems to us, both in what you said before

\footnotetext{
1 In this regard, Elliott (1993:78) comments: "To be holy, according to James, is to be whole - with respect to personal integrity, communal solidarity, and religious commitment."
} 


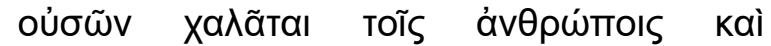

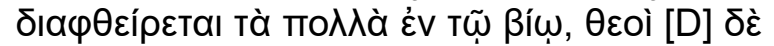

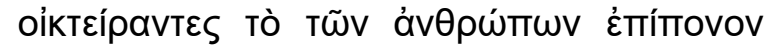

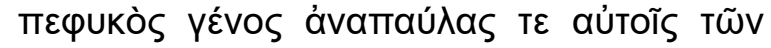

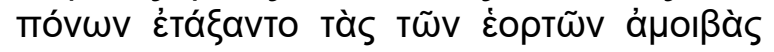

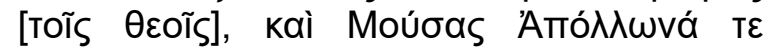

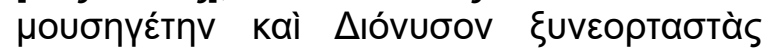

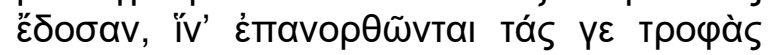

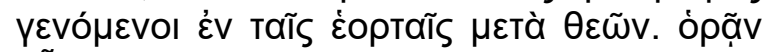

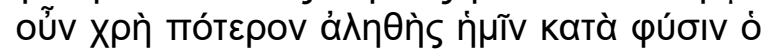

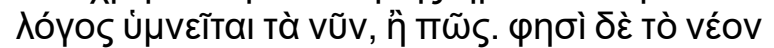

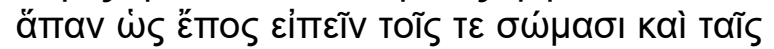

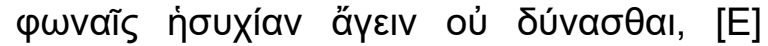

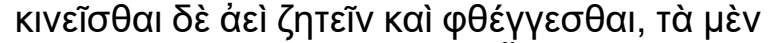

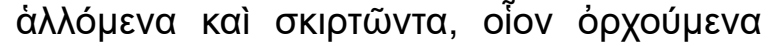

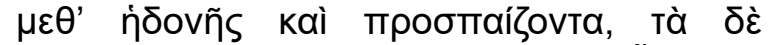

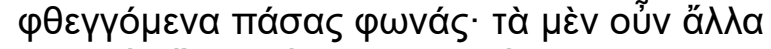

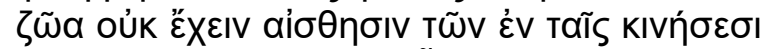

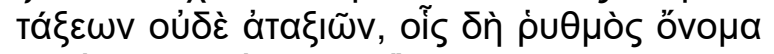

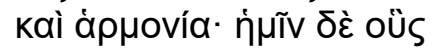

and in what you say now about education. ath. Very good. Now these forms of childtraining, which consist in right discipline in pleasures and pains, grow slack and weakened to a great extent [D] in the course of men's lives; so the gods, in pity for the human race thus born to misery, have ordained the feasts of thanksgiving as periods of respite from their troubles; and they have granted them as companions in their feasts the Muses and Apollo the master of music, and Dionysus, that they may at least set right again their modes of discipline by associating in their feasts with gods. We must consider, then, whether the account that is harped on nowadays is true to nature? What it says is that, almost without exception, every young creature is incapable of keeping either its body or its tongue quiet, [E] and is always striving to move and to cry, leaping and skipping and delighting in dances and games, and uttering, also, noises of every description. Now, whereas all other creatures are devoid of any perception of the various kinds of order and disorder in movement (which we term rhythm and harmony), to us men the very gods, who were given, as we said, to be our fellows in the dance, have granted the pleasurable perception of rhythm and harmony, whereby they cause us to move

\section{Plato, Phaedrus $253 \mathrm{C}-\mathrm{E}$}

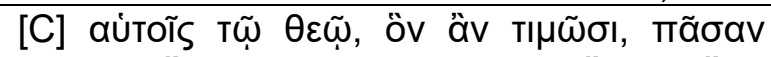

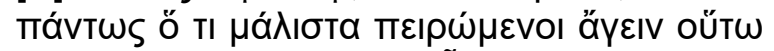

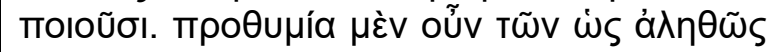

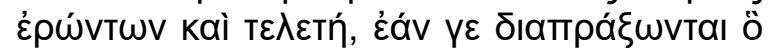

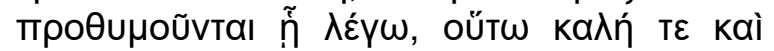

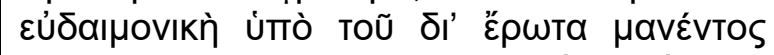

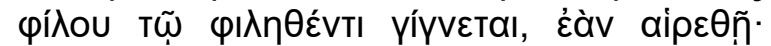

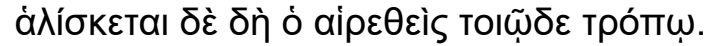

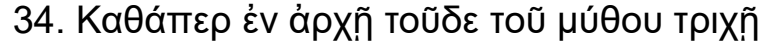

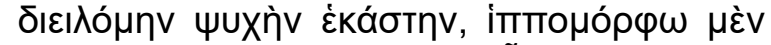

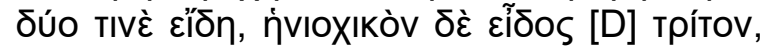

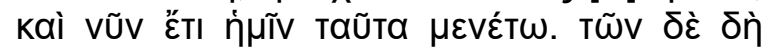

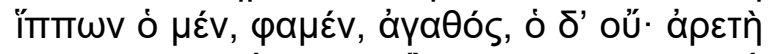

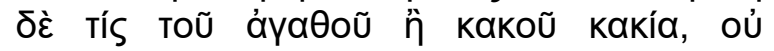

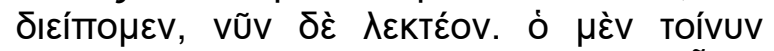

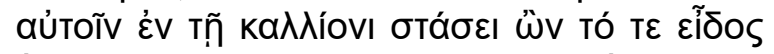

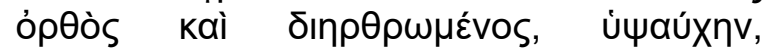

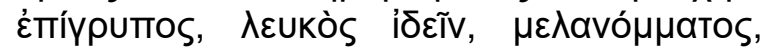

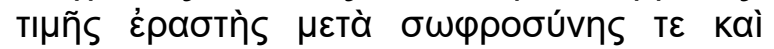

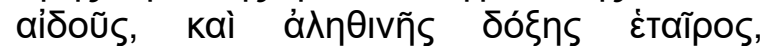

[C] of the god whom they honour. Thus the desire of the true lovers, and the initiation into the mysteries of love, which they teach, if they accomplish what they desire in the way I describe, is beautiful and brings happiness from the inspired lover to the loved one, if he be captured; and the fair one who is captured is caught in the following manner:-

In the beginning of this tale I divided each soul into three parts, two of which had the form of horses, [D] the third that of a charioteer. Let us retain this division. Now of the horses we say one is good and the other bad; but we did not define what the goodness of the one and the badness of the other was. That we must now do. The horse that stands at the right hand is upright and has clean limbs; he carries his neck high, has an aquiline nose, is white in colour, and 


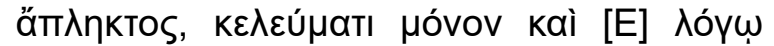

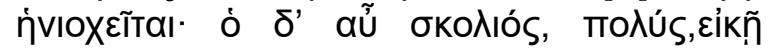

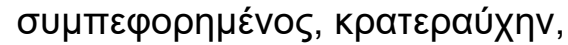

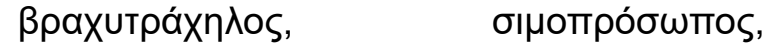

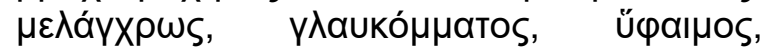

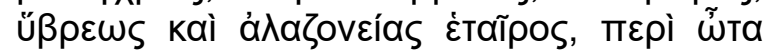

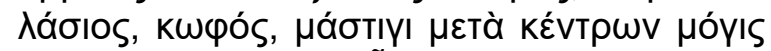

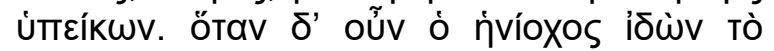

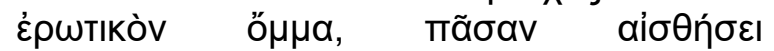

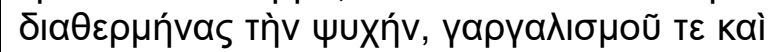
по́Өou has dark eyes; he is a friend of honour joined with temperance and modesty, and a follower of true glory; he needs no whip, but is guided only by the word of command and by reason. [E] The other, however, is crooked, heavy, ill put together, his neck is short and thick, his nose flat, his colour dark, his eyes grey and bloodshot; he is the friend of insolence and pride, is shaggy-eared and deaf, hardly obedient to whip and spurs. Now when the charioteer beholds the loveinspiring vision, and his whole soul is warmed by the sight, and is full of the tickling and

\begin{tabular}{|c|c|}
\hline \multicolumn{2}{|c|}{ James 3:1-3,16 } \\
\hline 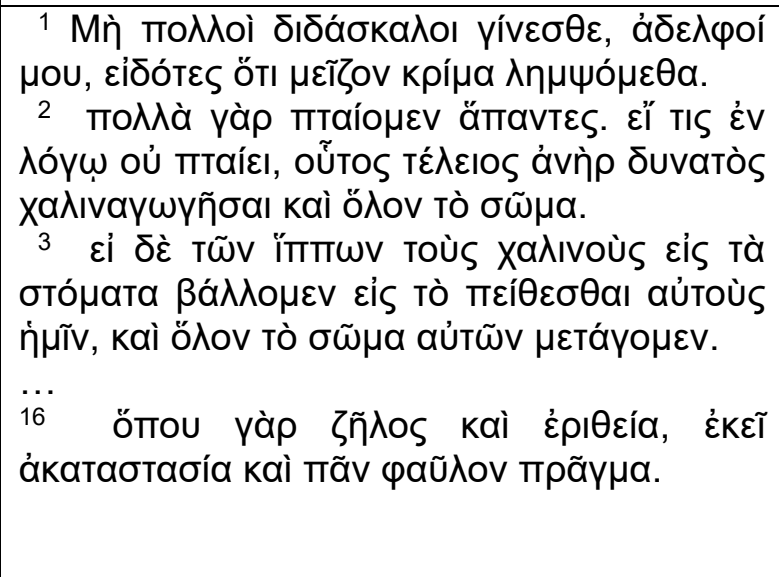 & $\begin{array}{l}{ }^{1} \text { Not many of you should become teachers, } \\
\text { my brothers and sisters, for you know that } \\
\text { we who teach will be judged with greater } \\
\text { strictness. 2 For all of us make many } \\
\text { mistakes. Anyone who makes no mistakes in } \\
\text { speaking is perfect, able to keep the whole } \\
\text { body in check with a bridle. }{ }^{3} \text { If we put bits } \\
\text { into the mouths of horses to make them obey } \\
\text { us, we guide their whole bodies } \\
\ldots \\
16 \text { For where there is envy and selfish } \\
\text { ambition, there will also be disorder and } \\
\text { wickedness of every kind. }\end{array}$ \\
\hline
\end{tabular}

In James 3:1-3, mature (teleios) is expressed focusing on the tongue as a theme - " For all of us make many mistakes. Anyone who makes no mistakes in speaking is perfect, able to keep the whole body in check with a bridle." For the author of James' Epistle, the tongue is regarded as the representative organ in the whole body, which should be controlled, noticing the tongue's devastating power. Thus, in the Epistle of James, one of the characteristics of maturity is to control the tongue, noting the tongue's influence on others.

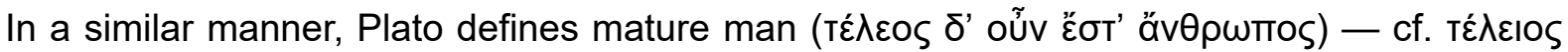

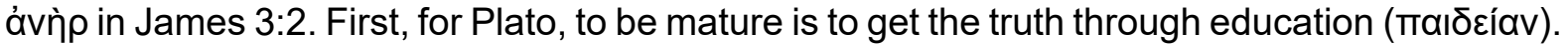
Therefore, a child is considered as an immature being in need of education, compared to a grown-up as a mature being. Second, for both the authors of James' Epistle and Plato's works, body and tongue are the objects to be properly controlled - In Plato (Laws $653 \mathrm{~A}-\mathrm{E}$ ), the children are incapable of leaving either body ( $\sigma \omega \dot{\mu \alpha \sigma ı)}$ ) or tongue ( $\varphi \omega v \alpha i ̃ \varsigma)$ quiet as an immature being.

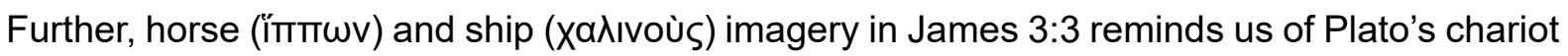
allegory (Phaedrus $253 \mathrm{C}-\mathrm{E}$ ) in that both the author of James' Epistle and Plato use horse imagery. In James 3:3, a bit is described as a small one that can control a much larger one, a horse; a ship is depicted as one that can be controlled by a tiny rudder. Similarly, logos' control over epithumia in Plato's chariot allegory (Phaedrus $253 \mathrm{C}-\mathrm{E}$ ) implies that one can control the other one - Plato uses chariot allegory to explain the human's psyche. According to Plato, the human psyche is a tripartition that is made up of logos (charioteer), thumos (tamed white horses), and epithumia (untamed black horses). In a sound psychic state, logos has control 
over both thumos and epithumia. ${ }^{2}$ Above all things, it is noteworthy that the author of the Epistle of James uses the horse and ship imagery for emphasising the necessity of controlling the tongue as an indicator of maturity, whereas, Plato uses chariot allegory for striking the necessity of controlling both thumos and epithumia by logos in the aspect of psyche which refers to psychic maturity.

Based on the above-mentioned discussions, one can conclude that the author of James owes his conceptual framework here to Plato's writings in terms of maturity (teleios). Like Plato, James focuses on the maturity of body and tongue (The author of the Epistle of James focuses especially on the matter of maturity of the tongue). Yet, even if the author of the Epistle of James is indebted to Plato's chariot allegory, it seems, the author of James' Epistle uses Plato's chariot allegory not for the psychic maturity of controlling both thumos and epithumia by logos, but the maturity of body and tongue.

\begin{tabular}{|c|c|}
\hline \multicolumn{2}{|c|}{ Philo, Allegorical Interpretation 3.147} \\
\hline 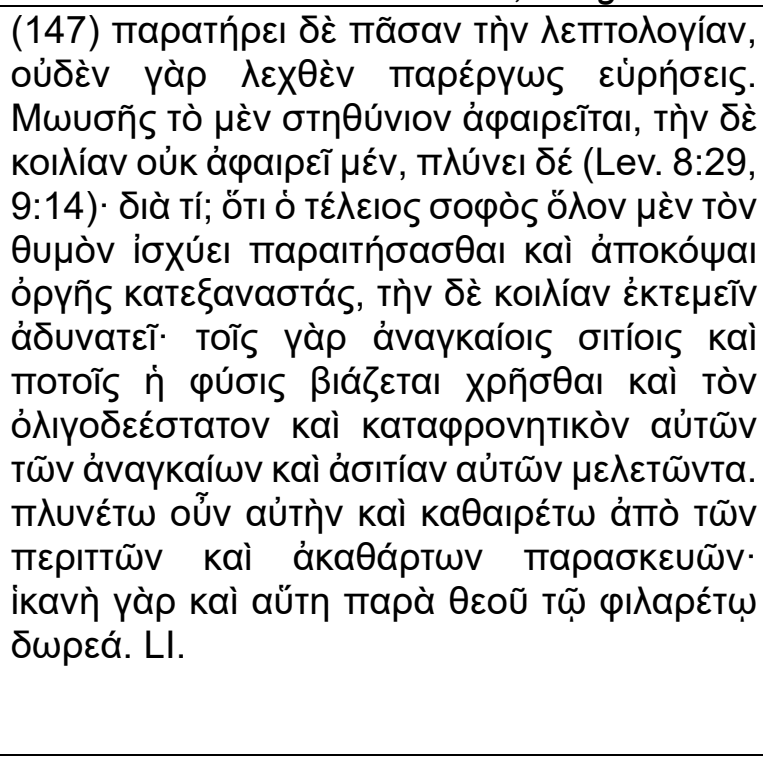 & $\begin{array}{l}\text { [147] Do not let any subtle point escape your } \\
\text { notice, for you will not find a single pointless } \\
\text { expression. Moses removes the breast; the } \\
\text { belly he does not remove, but washes (Lev. } \\
8: 29,9: 14 \text { ). Why is this? Because the perfect } \\
\text { wise man can, by wholly renouncing anger, } \\
\text { utterly avert and drive off the uprising of the } \\
\text { spirited element in him, but to exscind the } \\
\text { belly he is powerless. Even the man of } \\
\text { fewest needs who scorns the very } \\
\text { necessaries of life and trains himself in } \\
\text { abstinence from them, is forced by nature to } \\
\text { take necessary food and drink. Let him } \\
\text { therefore wash the belly and cleanse it from } \\
\text { superfluous and unclean provisions; for this } \\
\text { too is a sufficiently great gift from God to the } \\
\text { lover of virtue. }\end{array}$ \\
\hline
\end{tabular}

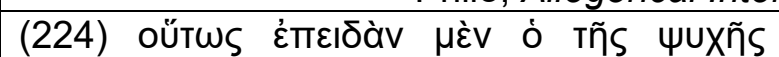

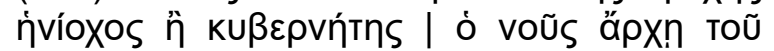

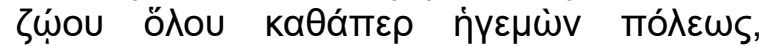

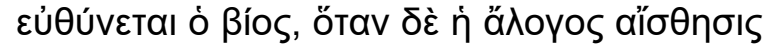

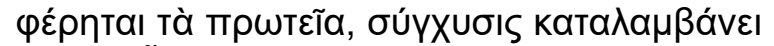

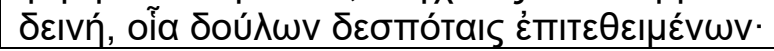

[224] Just so, when Mind, the charioteer or helmsman of the soul, rules the whole living being as a governor does a city, the life holds a straight course, but when irrational sense gains the chief place, a terrible confusion overtakes it, just as when slaves have risen

\footnotetext{
2 In James 4:1 pleasure (i்סovw̃v) plays a role in kindling contentions. Compared with James 4:1, through the grasp of rational account based on education one can control pleasure (ท்סovì) in Plato, Laws 653 A-E: "When pleasure and love, and pain and hatred, spring up rightly in the souls of those who are unable as yet to grasp a rational account"; Even logos allegorised as a charioteer in psychic understanding is linked to ruling elite [philosophers] with reason and epithumia allegorised as black horses in psychic understanding is linked to mass through city-soul analogy in Plato, Republic 8. 543A547C (Evigenis, 2002:590-610). In harmony with this, Plato argues that in an ideal city [the aristocratic city], one of five regimes Plato suggests, ruling elite [philosophers] with reason in society are controlling over mass (McAleer, 2020:229).
} 


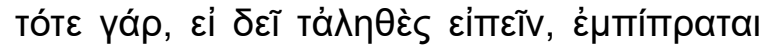
$\varphi \lambda \varepsilon \vee o ́ \mu \varepsilon v o \zeta$ ó voũ

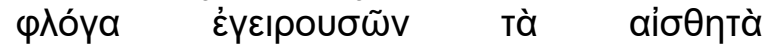

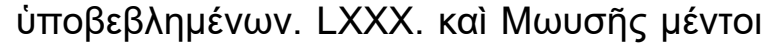

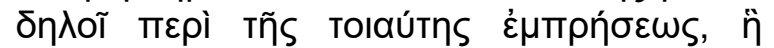

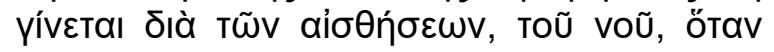
$\lambda \varepsilon ́ \gamma \eta$ against masters: for then, in very deed, the mind is set on fire and is all ablaze, and that fire is kindled by the objects of sense which Sense-perception supplies. LXXX. Moses, moreover, gives intimations of such a conflagration of the mind as this, occasioned by the senses, when he says:

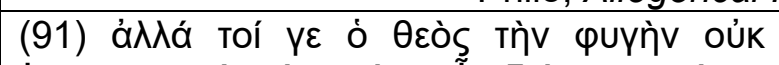

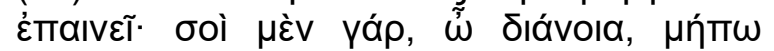

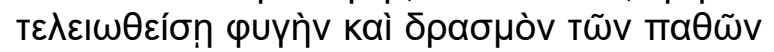

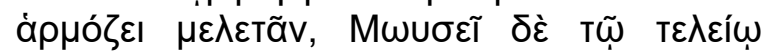

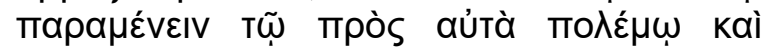

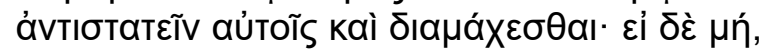

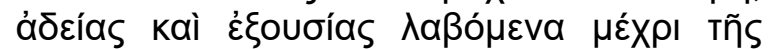

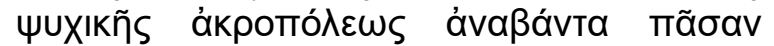

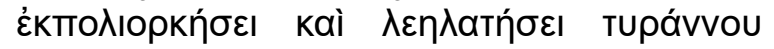

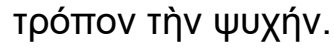

terpretation 2.91

[91] But, mark you, God does not applaud his flight. For while it well befits thee, $\mathrm{O}$ my mind, who art not yet made perfect, to get practice by flying and running away from the passions, it befits Moses, the perfect one, not to desist from the warfare against them, but to resist them and fight it out. Otherwise, finding nothing to alarm or to stop them, they will make their way up to the very citadel of the soul, and storm and plunder the whole soul after the fashion of a lawless ruler.

\begin{tabular}{|c|c|}
\hline \multicolumn{2}{|c|}{ James $3: 1-8,16$} \\
\hline 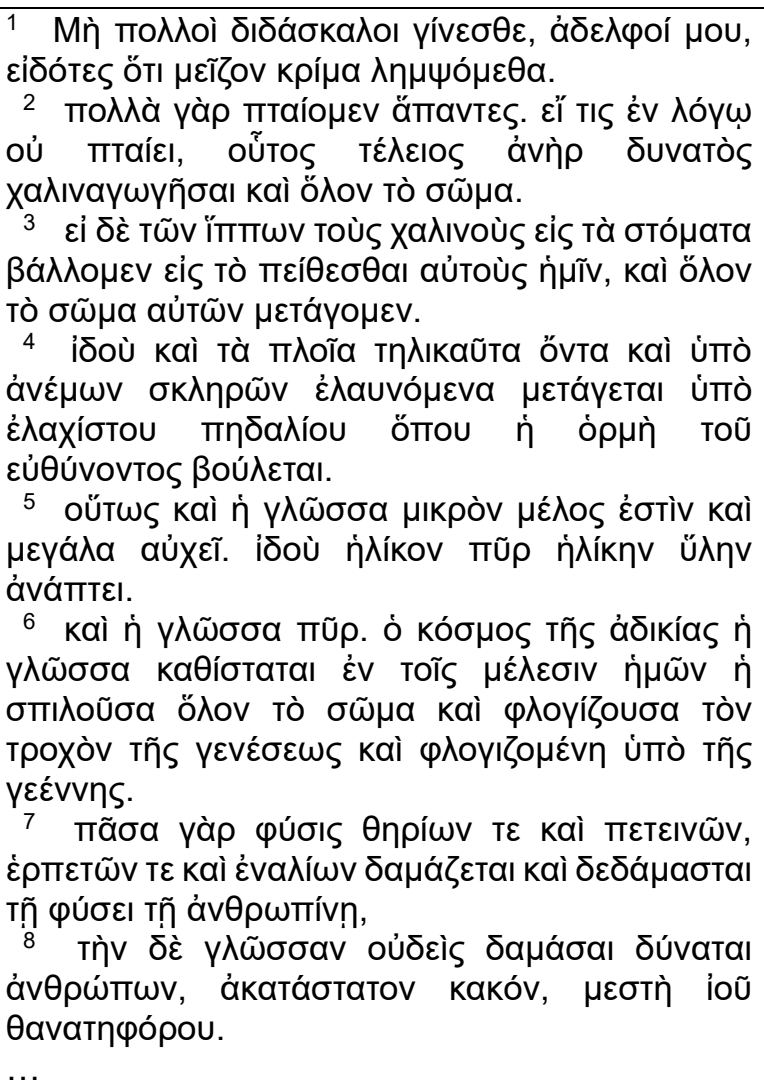 & $\begin{array}{l}{ }^{1} \text { Not many of you should become teachers, my } \\
\text { brothers and sisters, for you know that we who } \\
\text { teach will be judged with greater strictness. }{ }^{2} \text { For } \\
\text { all of us make many mistakes. Anyone who } \\
\text { makes no mistakes in speaking is perfect, able to } \\
\text { keep the whole body in check with a bridle. }{ }^{3} \text { If we } \\
\text { put bits into the mouths of horses to make them } \\
\text { obey us, we guide their whole bodies. }{ }^{4} \text { Or look at } \\
\text { ships: though they are so large that it takes } \\
\text { strong winds to drive them, yet they are guided } \\
\text { by a very small rudder wherever the will of the } \\
\text { pilot directs. }{ }^{5} \text { So also the tongue is a small } \\
\text { member, yet it boasts of great exploits. } \\
\text { How great a forest is set ablaze by a small fire! } \\
{ }^{6} \text { And the tongue is a fire. The tongue is placed } \\
\text { among our members as a world of iniquity; it } \\
\text { stains the whole body, sets on fire the cycle of } \\
\text { nature, and is itself set on fire by hell. }{ }^{7} \text { For every } \\
\text { species of beast and bird, of reptile and sea } \\
\text { creature, can be tamed and has been tamed by } \\
\text { the human species, }{ }^{8} \text { but no one can tame the } \\
\text { tongue-a restless evil, full of deadly poison } \\
\ldots \\
{ }^{1} \text {. }\end{array}$ \\
\hline 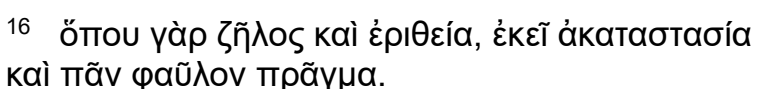 & \\
\hline
\end{tabular}

Accepting the understanding of a psychical tripartition of Plato, Philo defines true human maturity (teleios) as getting rid of thumos and controlling epithumia - "Because 'the perfect 


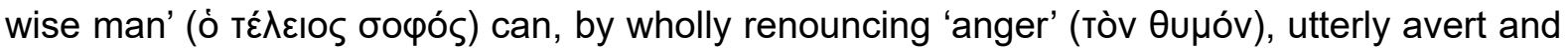
drive off the uprising of the spirited element in him." (Philo, Allegorical Interpretation 3.147) /

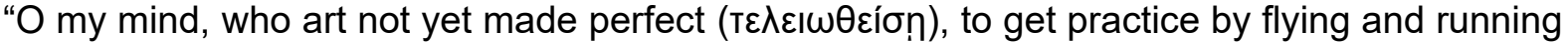

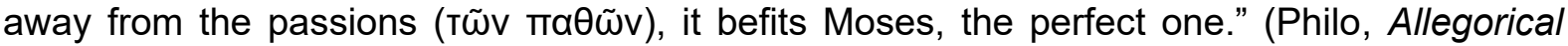
Interpretation 2.91). In terms of this, Satlow (2008:506) opines: "True human perfection for Philo, then, entails both excising the seat of anger and rage and standing up to and fighting the inevitable passions."

Philo, furthermore, applies psychical maturity (teleios) into horse and ship imagery in Philo (Allegorical Interpretation 3.224). For Philo, logos, rational part allegorised as charioteer and helmsman, are described as the controlling subject which can control irrational senses.

Similar to Philo, the author of James' Epistle uses horse and ship imagery for explaining the

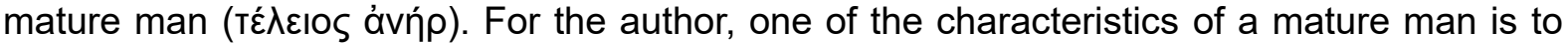
control the tongue to control the whole body, similar to a bit and rudder which could even control a horse and a ship respectively.

Considering the above discussions, it appears that the author of James' Epislte alludes to Philonic imagery in the light of the theme of control, particularly the imageary of a horse and a ship. And to both authors, maturity (teleios) is related to the matter of control.

Even if there is intertextual relevance between James 3:1-8;16 and Philo's writings (Philo, Allegorical Interpretation $2.91 ; 3.147$; 3.224 ), clear discontinuity is that Philo uses imagery as to horse and ship for the psychical controlling matter - epithumia and thumos as the objects which should be controlled by logos, whereas, the author of the Epistle of James uses imagery as to horse and ship to deal with contol, especially the tongue.

\title{
Platonic or Philo's teleios (James 1:17) as one of the divine attributes?
}

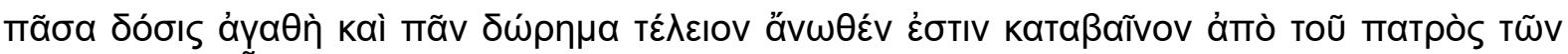

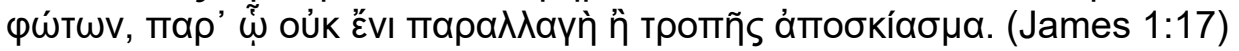

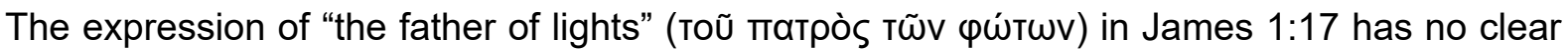
antecedents from both Jewish and Hellenistic texts (McCartney, 2009:108). Even if clear

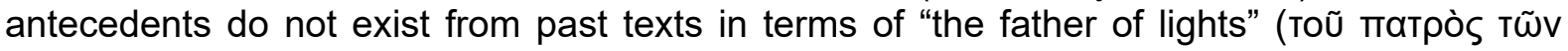

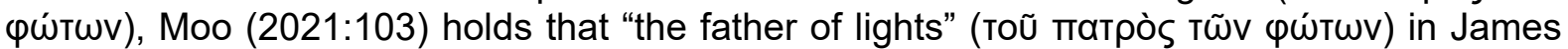
$1: 17$ refers to "God's creation of the heavenly bodies", supposing that the home of "the father of lights" (тои̃ татро̀ऽ тũv $\varphi \omega ́ t \omega v)$ is Jewish tradition:

\begin{abstract}
James therefore cites God's creation of the heavenly bodies as evidence of his power and continuing care for the world. The OT frequently makes a similar point (see Job 38:4-15, 19-21, 31-33; Ps 136:4-9; Isa 40:22, 26; and note also Sirach 43:1-12).
\end{abstract}

Even if there is an observation from McCartey (2009:108) - the expression of "the father of

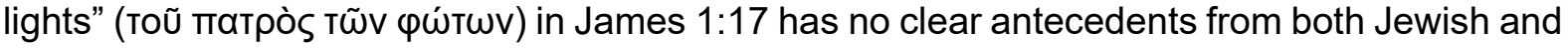
Hellenistic texts, one can find the home as to the expression of "the father of lights" (Toũ

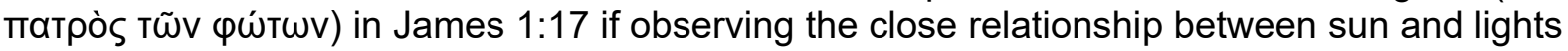
as the characteristic aspect. At least, in the empirical aspect, "the father of lights" (тог̃ патрò TŨv $\varphi \omega ́(\omega v)$ can refer to "sun" at the first phase, ultimately "God" in James 1:17 in that sun plays a role in a father of lights since all lights are generated by the sun like the relation 
between a father and sons.

Philo stands in the tradition where God is good and described as the sun, similar to James 1:17. Philo calls God "the Good" (Philo, Allegorical Interpretation 1.14,47). And for Philo, God is "the sun of sun" (Philo, On the Special Law 1. 51, 279). In addition, as in James 1:17, God is described as an unchangeable being, comparing God's unchangeableness with human's changeableness (Philo, Allegorical Interpretation 2.33).

In the Republic of Plato, unlike James 1:17, a god isn't being described as a sun: Plato uses a sun for expounding the meaning of "good" (Analogy of the sun: Republic 6. 507B-509C). ${ }^{3}$ As a sun not only provides nourishment for the growth but also makes the objects visible, a sun symbolises "good" (Plato, Republic 6. 509B). But, the characteristic of good a sun, is closely linked to Plato's notion "Idea of good, a god", considering that characteristic of the good is related to the essence of good, namely, "Idea of good, a god". 4

If the variation as to the above-mentioned point is excluded, the father of lights, sun, God in James 1:17 sounds the same note as "the god as Idea of good" from Plato. According to Plato,

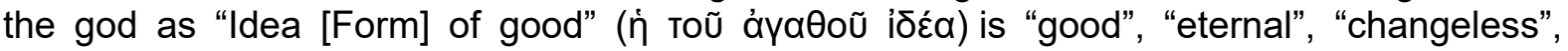
"perfect", "existing not only in the imperfect universe (imminent), but also apart from it (transcending)" (Burton, 1909:354-355). In this regard, Edwards' view (1978:309) is noteworthy:

In the second of book of the Republic, Plato states the Greek concept of the perfect as the utterly unchanging which has dominated classical supernaturalism through the centuries, despite the fact that it is nowhere to be found in Biblical religion. Plato maintained that the most perfect beings are the most self-sufficient, thus ruling out the possibility that perfection could be changed by anything outside itself (and thus ruling out the possibility that a perfect being could be affected in any way by the world, though not that it could have effects upon the world). Further, God who is 'in every perfect' could not be changed even from within by himself.

As in Plato, the author of the Epistle of James asserts that the "good" (áyaӨń) and "perfect"

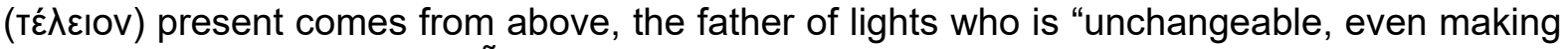

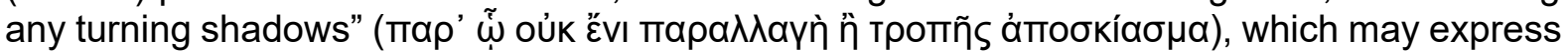
God's characteristics - good, perfect and unchangeableness.

\section{James $1: 17$}

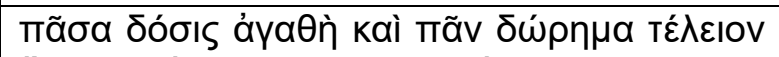

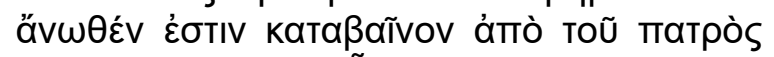

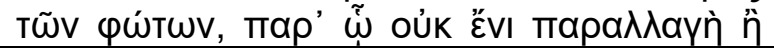
Every generous act of giving, with every perfect gift, is from above, coming down from the Father of lights, with whom there is no

\footnotetext{
${ }^{3}$ Noting the close relation between Plato's texts and Philo's texts with respect to the matter of "good and God", Wolfson (1962:1.202) opines: "Indeed Philo sometimes calls God "the Good" or "the true Good," but this is not in the sense that God is the idea of good; it is only in the sense of property of God, which, like all the other properties of God, is considered by Philo as designating the power or action of God." Thus, Wolfson (1962:1.201-2) judges that Philo's view as to "God and Good" is taken from the view of Plato; however, at least, while Philo doesn't accept the notion of "the idea of good" from Plato, Philo regards the good of God as the matter of property of God.

${ }^{4}$ Wolfson (1962:201) notes intertextual relevance between Plato and Philo, centering on the motif of sun: "Evidently having in mind the passages in Plato where the idea of the good might be taken as identical with God, he says that God is 'superior to virtue, superior to knowledge, superior to the good itself and the beautiful itself.' Evidently, again, having in mind Plato's analogy of the good to the sun, he substitutes God for good."
} 
In addition to these, Jesus who holds the divinity like God, is described as the being existing outside of time who can intervene in the world controlled by the flow of time (James 5:9), thereby transcending the rule of time - Jesus who holds the divinity is unlimited or infinite concerning time; for judgment, Jesus will intervene in the world in time (eschatology). ${ }^{5}$

James 5:9

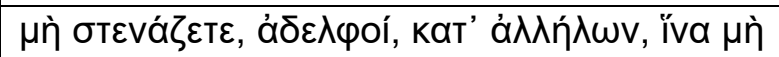

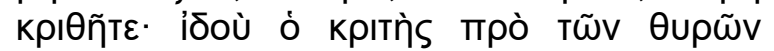

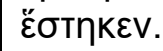

Beloved, do not grumble against one another, so that you may not be judged. See, the Judge is standing at the doors!

Thus, the perception of the author of the Epistle of James as to divinity characteristics owes to that of "Idea of good" from Plato or "the good characteristic of God" from Philo, centring on the motif of "a sun (the father of lights in James 1:17)". And furthermore, it is likely that the notion of "perfect", one of the divine attributes, is deduced from Plato or Philo's notions.

\section{Conclusion}

Teleios in the Epistle of James displays various understandings - the state of perfection, the notion relating to psychic undividedness, the concept relating to purity, maturity and one of the divine attributes. Thus, it is likely that the attempts to trace the origin of teleios in James' Epistle should be based on the semantic observation surrounding the term, teleios, from the pre-texts in the background of this Epistle's intertextual composition. Hartin's view that the use of teleios in the Epistle of James is rooted in the Hebrew Scriptures and the LXX as the Jewish coloured term seems fair if noting the aspects such as the state of perfection, the notion relating to psychical undividedness, and the concept relating to purity. However, if taking note of teleios as "maturity" and "one of the divine attributes", one might conclude that the understanding of James regarding teleios has been coloured by Hellenistic influence. Thus, through the term, teleios, one can gain a glimpse of the author's identity - it appears that the author of the Epistle of James was a well - educated Jew, knowing both traditions - Jewish and Hellenistic.

\section{References}

Allison, D. C. (2013). James, London: Bloomsbury T\&T Clark.

Dibelius, M. (1975). James, Philadelphia: Fortress.

Edwards, R. B. (1978). The Pagan Dogma of the Absolute Unchangeableness of God. Religious Studies, 14, 305-313.

Elliott, J. H. (1993). The Epistle of James in Rhetorical and Social Scientific Perspective Holiness-Wholeness and Patterns of Replication. Biblical Theology Bulletin: A Journal of Bible and Theology, 23(2), 71-81.

\footnotetext{
${ }^{5} \mathrm{As}$ to "God" in biblical tradition and "a god as the Idea of good" in Plato, the striking difference between them would be that "Plato neither asserts nor denies the personality of deity." Compared with this, in the biblical tradition, God is regarded as God who has personality (Burton, 1909:355).
} 
Evrigenis, I. D. (2002) The Psychology of Politics: The City-Soul Analogy in Plato's "Republic". History of Political Thought, 23(4), 590-610.

Grant, F. C. (1915). St. Paul and Stoicism, The Biblical World, 45(5), 268-281.

Hartin, P. J. (1999). A Spirituality of Perfection: Faith in Action in the Letter of James, Collegeville: The Liturgical Press. (2003). James, Collegeville: The Liturgical Press. (2012). Faith-in-Action: An Ethic of "Perfection", Center for Christian Ethics, 20-

28.

Hazony. Y. \& Johnson. D. (eds.) (2019). The Question of God's Perfection: Jewish and Christian Essays on the God of the Bible and Talmud, Leiden: Brill.

Heathcote, C. W. (1931). Plato: Great Philosopher and Teacher, Social Science, 6(3), 283287.

Johnson, L. T. (1995). The Letter of James, New Haven: Yale University Press.

Martin, R. P. (1988). James, Waco: Word Books, Publisher.

McAleer, S. (2020). Plato's 'Republic': An Introduction, Cambridge: Open Book Publishers.

McCartney, D. G. (2009). James, Grand Rapids: Baker Academic.

McKnight, S. (2011). The Letter of James, Grand Rapids: Wm. B. Eerdmans Publishing Co.

Moo. D. J. (2021). The Letter of James, Grand Rapids: Wm. B. Eerdmans Publishing Co.

Newton, M. (1985). The Concept of Purity as Qumran and in the Letters of Paul, Cambridge: Cambridge University Press.

Papadis, D. (2013). The Platonic Ideas: A New Interpretation. Phronimon, 14(1), 93-100.

Pennigton, J. T. (2017). The Sermon on the Mount and Human Flourishing: Theological Commentary, Grand Rapids: Baker Academic.

Russell, B. (2004). History of Western Philosophy, London: Routledge.

Sanni. A. \& Danladi M. (2019). Plato's Philosophy of Education and its Implications to Counselling. British Journal of Education, 7(4), 66-73.

Vaage, L. E. \& Wimbush, V. L. (eds.) (1999). Asceticism and the New Testament, New York: Routledge.

Varner, W. (2014). James: Evangelical Exegetical Commentary, Bellingham: Lexham Press. Von Leyden, W. (1967). Aristotle and the Concept of Law, Philosophy, 42(159), 1-19.

Wolfson, H. A. (1962). Philo vol. 1, Cambridge: Harvard University Press. 


\section{Texts}

Textual sources which will be used are as below for this research.

- Texts and English translations as to Plato's writings are from Loeb Classical Library.

- Texts and English translations as to Philo's writings are from Loeb Classical Library.

- Texts and English translations as to The Dead Sea Scrolls are from Study Edition of Florentino García Martínez \& Eibert J. C. Tigchelaar.

- Texts as to LXX are from Göttingen Septuaginta Vetus Testamentum Graecum.

- Texts respecting New Testament is from Novum Testamentum Graece $28^{\text {th }}$ (Aland, $K$., Aland, B., Karavidopoulos, J., Martini, C. M., \& Metzger, B. M.).

- Texts respecting Old Testament is from Biblia Hebraica Stuttgartensia (Gérard E. Weil, W. Rudolph, Deutsche Bibelgesellschaft, K. Elliger).

- English Translation as to Old Testament and New Testament is from New Revised Standard Version. 